Egyptian Journal of Aquatic Biology \& Fisheries

Zoology Department, Faculty of Science,

Ain Shams University, Cairo, Egypt.

ISSN $1110-6131$

Vol. 24(5): 403 - 411 (2020)

www.ejabf.journals.ekb.eg

\title{
Impacts of the climatic changes on the fishery activities Along Egyptian coast of Mediterranean
}

\author{
Noura H. S. Hassan* and Ebtessam E. E. Mohamed \\ National Institute of Oceanography and Fisheries, Egypt.
}

*Corresponding Author: drnourahassan@gmail.com

\section{ARTICLE INFO Article History: \\ Received: Jan. 5, 2020 \\ Accepted:Aug. 9, 2020 \\ Online:Nov. 14, 2020}

Keywords:

Climate change,

Mediterranean coast,

Coastal erosion,

human activities

\begin{abstract}
This research is mainly directed to study the impacts of the climatic changes on the fishery activities along the Egyptian coast of the Mediterranean. Such a major aim can be achieved through the study of a group of sub- objectives: identify some of the social and economic characteristics of the respondents, identify the knowledge of the respondents about the climate changes and their causes, identify the knowledge of the respondents about the environmental impacts of such climate changes (Coastal erosion and diminishing marine resources). A well prepared and pretested questionnaire was used to collect data needed for this research. Data were gathered from (152) respondents. The data were analyzed statistically by using SPSS program. It is clearly identified from the data analysis that, the averages of the social and economic characteristics of the respondents were in the middle category and the lower one, the lowest sources of information used by the respondents were fish extension.
\end{abstract}

\section{INTRODUCTION}

Climate changes is considered one of the most important issues of today's world. It is defined as an average of weather conditions, typically measured over 30 years, since 1880, global average temperatures have increased by $1.53^{\circ} \mathrm{F}$ (Leigh and Wulfhorst, 2017), refers to any distinct change in measures of climate lasting for a long period of time. In other words, "climate change" means major changes in temperature, rainfall, snow, or wind patterns lasting for decades or longer (EPA, 2009). It may be as a result of many reasons (Annetta et al., 2014):

1. Natural factors, such as changes in the sun's energy or slow changes in the Earth's orbit around the sun.

2. Natural processes within the climate system (e.g., changes in ocean circulation).

3. Human activities that change the atmosphere's make-up (burning fossil fuels) and the land surface (cutting down forests, planting trees, the built environment) (EPA, 2009). 
Many recent studies have been devoted to global, hemispherical, or regional longterm temperature variations (Jones, 1988; Schaefer and Manfred, 2009). Generally they found that, on a global scale, there is indication but for northern hemisphere the increase is between $0.5-0.7^{\circ} \mathrm{Csince} 1865$ (Maged and Ebtisam, 2016).

The international Panel on Climate Change (IPCC) has clearly identified temperature trends on a global scale, detecting on average surface temperature increase of about $0.60^{\circ} \mathrm{c}$ over the $20^{\text {th }}$ century; it was shown that pronounced warming occurred over two periods, i.e. 1910 - 1945 and 1976 - 2000. The 1990s were the warmest decade experienced, and 1998 was the warmest individual year from the instrumental record (IPCC, 2001a; Domroes and Attia, 2005). As clearly shown, temperature increase on a mean global scale resulted from a pronounced winter warming according to the IPCC, (IPCC, 2001b).

Naturally, long-term climate changes occur in responses to fluctuations in the amount of solar energy reaching the earth, changing ocean current, formation or loss of ice sheets, and many other causes (Clyde et al., 2009). This throws sun-blocking particles into the stratosphere to cool the Earth, or the Pacific Ocean event known as El Niño, which transfers thermal energy from one part of the earth to another (Clyde et al., 2004).

In addition to these natural causes of climate variability, human activities influence the climate in many ways. Land use changes like the irrigation of historically semi-arid areas of farmland, the paving and development of sprawling urban areas, the draining of wetlands, and increased aerosols in atmosphere are all anthropogenic forces disturbing our climate system. Perhaps the most significant human influence today is the increasing concentrations of greenhouse gases in the atmosphere, mainly carbon dioxide $\left(\mathrm{CO}_{2}\right)$ and methane $\left(\mathrm{CH}_{4}\right)$, which have modified the Earth-atmosphere energy balance, leading to a warming atmosphere (Clyde et al., 2009).

Egypt is one of the countries most affected by the negative effects of climate changes. These include: sea level rise, water poverty, deterioration of public health and ecosystems, resulting in billions of economic losses and food security,(Climate change in Egypt, https://ar.wikipedia.org/wiki/).

Stresses on marine and coastal ecosystems are expected to be exacerbated by direct and indirect climate change impacts such as sea level rise, sea surface temperature increases, ocean acidification, and increased intensity of storms and hurricanes. The direct and indirect impacts of climate change drivers will result in changes at the level of the harvest and post-harvest sectors, as well as at the broad national level, (Graeme and Edward, 2009).

In regard to commercial the impacts on the harvest sector is going to affect boats, gears and fishing techniques. Post-harvest activities may be impacted anywhere along the value chain after the catch is landed, such as handling and transportation, preserving, storing and distribution of fish and fishery products, at the national level. Climate change also can impact the level of revenues, exports, per capita fish supply, and contributions of the fisheries sector to employment and GDP. This sure require changes to current management and legislation of fisheries (Iris and Hazel, 2017). 
Therefore, the present study has been proposed to know the effect of climate changes on fishing activities of fishermen and more specifically to:

1- identify the social and economic characteristics of the respondents.

2- identify to what extent of the respondents are aware and interested about the climate changes and their effects.

3- identify the reaction of the respondents about the environmental impacts of such climate changes (Coastal erosion and diminishing marine resources).

\section{MATERIALS AND METHODS}

The aim of this research is to identify the impact of climatic changes on fishery activities and fishermen. A questionnaire was designed to obtain their awareness and information concerning the impact of climatic change. An interviews were done with fishermen at three different fish ports which are Damieta, Alburullus and Rosetta. To verify the validity and stability of the sample, a pretest was done and then repeat on the same people after a period of time. and it clear that there are no difference between both answers; the first time and the second time. The number of samples was 152 from 6282 respondents at the rate of about $(2.5 \%)$. The questions prepared were designed to provide responses from respondents covering the research objectives. Table 1 gives the number of interviewers in three ports (GAFRD, 2016).

Table 1. The number of interviewers in three fish ports.

\begin{tabular}{lll}
\hline Port & Sample & Population \\
\hline Damietta & 81 & 861 \\
Albrolos & 35 & 362 \\
Rosetta & 36 & 5059 \\
Total & $\mathbf{1 5 2}$ & $\mathbf{6 2 8 2}$ \\
\hline Source: Computed from sample data. & &
\end{tabular}

\section{RESULTS}

\section{Socio characteristics of interviewers:}

The ages of interviewers were divided into three categories; less than 39 years, between 39 - 65 year and more than 65 year. The greater category $(64.5 \%)$ were in the range between $39-65$ year in as shown Table 2. This means that the new generation are not included in professional fishing.

Table 2. Age of interviewers.

\begin{tabular}{lcc}
\hline Category & number & \% \\
\hline The lower category (Less than 39) & 28 & 18.4 \\
Middle category (39 less than 65) & 98 & 64.5 \\
Top category (66 and more) & 26 & 17.1 \\
Total & $\mathbf{1 5 2}$ & $\mathbf{1 0 0}$ \\
\hline Source: Computed from sample data
\end{tabular}


Moreover, $97.4 \%$ of the questionair population are married, which confirm the necessity of their work (Table 3). Also, 76.3\% of them have from 3-6 children (Table 4); this means that the fishermen believe that their children support them in their work and life.

Table 3. The social situation.

\begin{tabular}{lcl}
\hline The social situation & Number & \% \\
\hline Married & 148 & 97.4 \\
Single & 4 & 2.6 \\
Total & $\mathbf{1 5 2}$ & $\mathbf{1 0 0}$ \\
\hline Source: Computed from sample data. & &
\end{tabular}

Table 4. Number of children.

\begin{tabular}{lll}
\hline Category & Number & \% \\
\hline $\begin{array}{l}\text { The lower category } \\
\text { (Less than 3) }\end{array}$ & 26 & 17.1 \\
$\begin{array}{l}\text { Middle category } \\
\text { (3 less than 6) }\end{array}$ & 116 & 76.3 \\
$\begin{array}{l}\text { Top category } \\
\text { (6 and more) }\end{array}$ & 10 & 6.6 \\
Total & $\mathbf{1 5 2}$ & $\mathbf{1 0 0}$ \\
\hline Source: computed from sample data. & &
\end{tabular}

About $62.5 \%$ of the the investigated samples can read and write (Table 5). This means they have limited culture and life experiences supplied are from parents, practices and other sources like Tv.

Table 5. Educational status.

\begin{tabular}{lll}
\hline Category & Number & \% \\
\hline Illiterate & 9 & 5.9 \\
Read and write & 95 & 62.5 \\
Primary & 26 & 17.1 \\
Intermediate & 22 & 14.5 \\
Academic & 0 & 0 \\
\hline Total & $\mathbf{1 5 2}$ & $\mathbf{1 0 0}$ \\
\hline
\end{tabular}

\section{Economic characteristics:}

Most of interviewers (57.9\%) are using the trawl method to catch fish. While $21.7 \%$ of them use the purse seine method and $15.1 \%$ use the longline one (Table 6). 
Table 6. Types of the fishing method.

\begin{tabular}{lcc}
\hline Method & number & \% \\
\hline Trawl & 88 & 57.9 \\
Longline & 23 & 15.1 \\
Mechanical & 3 & 2 \\
Purse seine & 33 & 21.7 \\
Trammel net & 5 & 3.3 \\
Total & 152 & 100 \\
\hline Source: Computed from sample data. & &
\end{tabular}

The field experiences of the investigated population ranged between less than 17 years $(45.4 \%)$ and up to 34 years $(42.1 \%)$ as shown in Table 7 . Asking them about their income, $52 \%$ refuse to answer and $48 \%$ mentioned that their income is little. This is due to their belief about envy and they are afraid from taxes (Table 8).

Table 7. Field experience of respondents.

\begin{tabular}{lcc}
\hline Category & Number & \% \\
\hline $\begin{array}{l}\text { Lower category (Less } \\
\text { than 17) }\end{array}$ & 69 & 45.4 \\
$\quad \begin{array}{l}\text { Middle category } \\
\text { (17 - 34) }\end{array}$ & 64 & 42.1 \\
$\quad \begin{array}{l}\text { Top category } \\
\text { (34 and more) }\end{array}$ & 19 & 12.5 \\
$\quad$ Total & $\mathbf{1 5 2}$ & $\mathbf{1 0 0}$ \\
\hline Source: Computed from sample data. & &
\end{tabular}

Table 8. Income of respondents.

\begin{tabular}{lcc}
\hline Type of reply & Number & \% \\
\hline Agreed to tell & 79 & 52 \\
Deny to tell & 73 & 48 \\
Total & $\mathbf{1 5 2}$ & $\mathbf{1 0 0}$ \\
\hline Source: Computed from sample data. & &
\end{tabular}

\section{Environmental impacts of climate changes:}

Most of the surveyed population $(87.5 \%$ ) heard about climatic changes, but many of them do not understand the meaning of this expression. When asking the respondents about the cause, $63.8 \%$ of them told it refer to increase of air temperature and melting of ice $(56.6 \%)$ and increase of gases emitted to the atmosphere $(73.7 \%)$ and the emission of gases due to human activity (69.1\%) and due to fires of rice hay $(73.7 \%), 40.8 \%$ of the population said that there is increase in windy days with dust, and the others disagree. Asking them about depletion in fish production due to climatic change and increase in air temperature $34.9 \%$ disagree. While $42.1 \%$ said that the fish quality is affected by increasing air temperature, $28.9 \%$ said it is the same while $28.9 \%$ disaree as showed in Table 9. 
Table 9. Environmental impacts of climate changes.

\begin{tabular}{|c|c|c|c|c|c|c|}
\hline \multirow{2}{*}{ Phrase } & \multirow{2}{*}{$\begin{array}{l}\text { Agree } \\
\text { Number }\end{array}$} & \multicolumn{3}{|c|}{ Not sure } & \multicolumn{2}{|c|}{ Did not agree } \\
\hline & & $\%$ & Number & $\%$ & Number & $\%$ \\
\hline $\begin{array}{l}\text { 1. Is there a so-called climate } \\
\text { change? }\end{array}$ & 133 & 87.5 & 15 & 9.9 & 4 & 2.6 \\
\hline $\begin{array}{l}\text { 2. There is no sea level change } \\
\text { either minimum or } \\
\text { maximum. }\end{array}$ & 28 & 18.4 & 70 & 46.1 & 54 & 35.3 \\
\hline $\begin{array}{l}\text { 3. Some time, depletion in fish } \\
\text { production due to high } \\
\text { temperature. }\end{array}$ & 53 & 34.9 & 46 & 30.3 & 53 & 34.9 \\
\hline $\begin{array}{l}\text { 4. I notice the increase of } \\
\text { windy \& dusty days. }\end{array}$ & 62 & 40.8 & 62 & 40.8 & 28 & 18.4 \\
\hline 5. Erosion of coastal zone. & 109 & 71.7 & 37 & 24.3 & 6 & 3.9 \\
\hline $\begin{array}{l}\text { 6. Changing weather } \\
\text { conditions leds to reduction } \\
\text { of fish species }\end{array}$ & 64 & 42.1 & 44 & 28.9 & 44 & 28.9 \\
\hline $\begin{array}{l}\text { 7. Sea level goes up as a result } \\
\text { of increasing air } \\
\text { temperature. }\end{array}$ & 82 & 53.9 & 30 & 19.7 & 26.3 & 40 \\
\hline $\begin{array}{l}\text { 8. Pests, diseases and } \\
\text { epidemics are widespread } \\
\text { due to high temperatures. }\end{array}$ & 141 & 92.8 & 7 & 4.6 & 4 & 2.6 \\
\hline $\begin{array}{l}\text { 9. Significant changes occur in } \\
\text { weather conditions such as } \\
\text { severe summer temperatures } \\
\text { and high temperatures at } \\
\text { another time of the year. }\end{array}$ & 97 & 63.8 & 37 & 24.3 & 11.8 & 18 \\
\hline $\begin{array}{l}\text { 10. Melting of snow at cold } \\
\text { areas due to high } \\
\text { temperatures leds to sinking } \\
\text { of many coastal cities and } \\
\text { some islands. }\end{array}$ & 86 & 56.6 & 45 & 29.6 & 21 & 13.8 \\
\hline $\begin{array}{l}\text { 11. The outputs of human } \\
\text { activities (gases and fumes } \\
\text { from factories and brick } \\
\text { kilns) goes up temperature. }\end{array}$ & 105 & 69.1 & 37 & 24.3 & 10 & 6.6 \\
\hline $\begin{array}{l}\text { 12. Burning rice straw leds to } \\
\text { higher air temperature. }\end{array}$ & 112 & 73.7 & 33 & 21.7 & 7 & 4.6 \\
\hline $\begin{array}{l}\text { 13. Some fishermen increase } \\
\text { their fishing production of catfish } \\
\text { (aleafsha) }\end{array}$ & 75 & 49.3 & 43 & 28.3 & 34 & 22.4 \\
\hline
\end{tabular}

\section{Information sources:}

Asking the surveyed population about the source of their knowledge, $52.6 \%$ is from internet followed by radio programs (41.4\%), as showed in Table 10. 
Table 10. Information sources.

\begin{tabular}{lcccc}
\hline \multirow{2}{*}{ Source } & \multicolumn{2}{c}{ Not assisted } & \multicolumn{3}{c}{ Assisted } \\
\cline { 2 - 5 } & Number & \% & Number & $\%$ \\
\hline TV programs & 89 & 58.6 & 63 & 41.4 \\
Radio programs & 112 & 73.7 & 40 & 26.3 \\
Newspapers and magazines & 145 & 95.4 & 7 & 4.6 \\
Internet & 72 & 47.4 & 80 & 52.6 \\
Fishermen Associations & 131 & 86.2 & 21 & 13.8 \\
Fish Extension Authority & 151 & 99.3 & 1 & 0.7 \\
Fish extension & 152 & 100 & 0 & 0 \\
Relatives and friends & 143 & 94.1 & 9 & 5.9 \\
\hline Source: Computed from sample data. & & & &
\end{tabular}

The relationship between climate changes and fishing activities:

About $32.9 \%$ of population think that sea level rise causes depletion of fish catch. Only $18.4 \%$ of population said that sea level has led to the displacement of the population of Alexandria and Rashid from their homes and leaving their jobs, which confirms their attachment to their land and their homes. About 56.6\% agreed that changing weather conditions affects the health situation and $66.4 \%$ of the respondents said that they feel a gradual increase of air temperature each year. Some fishermen $(49.3 \%)$ believe that the nowadays seasons have changed due to relatively high temperatures, $70.4 \%$ of population said that the change of atmospheric conditions is due to human activity. These changes include rain fall period, and quantity (63.2\%), while $49.3 \%$ of them said that some fish species disappeared. Also, some fishermen decided to leave the work of fishering. Beside, $40.1 \%$ of them said that their income decreased and $40.1 \%$ of the population confirmed that they are going to change their fishing method as a result of rising sea level. Also, $64.5 \%$ said that they change the sites of fishing due to climatic change ( Table 11). 
Table 11. The relationship between climate change and fishing activities

\begin{tabular}{|c|c|c|c|c|c|c|}
\hline \multirow[t]{2}{*}{ Phrase } & \multicolumn{2}{|l|}{ Agree } & \multicolumn{2}{|c|}{ Not sure } & \multicolumn{2}{|c|}{ did not agree } \\
\hline & Number & $\%$ & Number & $\%$ & Number & $\%$ \\
\hline $\begin{array}{l}\text { 1. Sea-level rise is related to the decline in } \\
\text { sea fishing output. }\end{array}$ & 50 & 32.9 & 46 & 30.3 & 56 & 36.8 \\
\hline $\begin{array}{l}2 \text { - The sea level rise leads to the } \\
\text { displacement of the population of Alexandria } \\
\text { and Rashid from their homes and leave their } \\
\text { jobs. }\end{array}$ & 28 & 18.4 & 44 & 28.9 & 80 & 52.6 \\
\hline $\begin{array}{l}\text { 3. Changing weather conditions affects } \\
\text { the state of health. }\end{array}$ & 86 & 56.6 & 34 & 22.4 & 32 & 21.1 \\
\hline $\begin{array}{l}\text { 4. I feel a gradual rise of temperature every } \\
\text { year. }\end{array}$ & 101 & 66.4 & 45 & 29.6 & 6 & 3.9 \\
\hline $\begin{array}{l}\text { 5. Some fishermen believe that fishing } \\
\text { seasons have changed due to relatively high } \\
\text { temperatures. }\end{array}$ & 75 & 49.3 & 41 & 27 & 36 & 23.7 \\
\hline $\begin{array}{l}\text { 6.Current people's practices increase the } \\
\text { atmospheric changes we are experiencing. }\end{array}$ & 78 & 51.3 & 42 & 27.6 & 32 & 21.1 \\
\hline $\begin{array}{l}\text { 7.The atmosphere changed from what we } \\
\text { used to it. }\end{array}$ & 115 & 75.7 & 28 & 18.4 & 9 & 5.9 \\
\hline $\begin{array}{l}\text { 8. Recent years, I have noticed a change in } \\
\text { rainfall dates from year to year. }\end{array}$ & 107 & 70.4 & 31 & 20.4 & 14 & 9.2 \\
\hline $\begin{array}{l}\text { 9. Recent years, I have observed a change } \\
\text { in the amount of rainwater falling from one } \\
\text { year to another. }\end{array}$ & 96 & 63.2 & 34 & 22.4 & 22 & 14.5 \\
\hline $\begin{array}{l}\text { 10. Climate change has led to } \\
\text { disappearance of certain species of fish. }\end{array}$ & 75 & 49.3 & 40 & 26.3 & 37 & 24.4 \\
\hline $\begin{array}{l}\text { 11. Most fishermen have the desire to } \\
\text { leave their jobs due to lack of fish production. }\end{array}$ & 83 & 54.6 & 23 & 15.1 & 46 & 30.3 \\
\hline $\begin{array}{l}\text { 12. Your monthly income is lower than } \\
\text { before, or as it is. }\end{array}$ & 67 & 44.1 & 18 & 11.8 & 67 & 44.1 \\
\hline $\begin{array}{l}\text { 13.Different fishing methods have been } \\
\text { used for the sake of sea level rise. }\end{array}$ & 61 & 40.1 & 35 & 23.1 & 56 & 36.8 \\
\hline $\begin{array}{l}\text { 14. The locations of fishing I used to hunt } \\
\text { where I changed from the first }\end{array}$ & 98 & 64.5 & 9 & 5.9 & 45 & 29.6 \\
\hline
\end{tabular}




\section{RECOMMENDATIONS}

- Activating the role of fishery extension and fishermen associations to transfer information and knowledge to fishermen.

- Organizing awareness seminars for fishermen on climate change.

- Search for new fishing locations.

- To encourage the preservation of marine environment from pollution and human activities.

- There is a need to increase communication tools to help the people understand climate change.

- There is need to increase of open access.

- The public information must be improved.

- Increase awareness about climatic change.

\section{REFERENCES}

Annetta A. J.; Noel M. E. and Audrey B. (2014). Climate Change Impacts on Agriculture and their Effective Communication by Extension Agents. Journal of Extension, February 2014, 52 (1).

Climate Change in Egypt (2020) from: https://ar.wikipedia.org/wiki/

Clyde W. F.; Zierden D.; Breuer N.; Jackson J. and Brown C. (2004). Climate forecast and decision making in agriculture. Coop. Ext. Serv. Circ. ABE 352, Univ. Florida. Gainesville, FL. Retrieved July 20, 2009 from: http://edis.ifas.ufl.edu/AE267

Clyde W. F.; Norman E. B.; David Z. and Keith T. I. (2009). From climate variability to climate change: Challenges and Opportunities to Extension. Journal of Extension, April 2009, 47( 2).

Domroes M. and Attia T. (2005). Recent temporal and spatial temperature changes in Egypt. International Journal of Climatology, 25; 51-63.

IPCC (2001a). Climate Change, Working Group I, the Scientific Basis, United Nations Environment Programme (UNIP) and World Meteorological Organization (WMO).

IPCC(2001b). Impacts, Adaptation and Vulnerability United Nations Environmental Programme (UNIP) and world Meteorological organization (WMO), Climate change, Working Group $\Pi$.

Iris M. and Hazel A. O. (2017). Impacts of climate change on fisheries in the coastal and Marine environments of Caribbean Small Island Developing States (SIDS).Caribbean Marine climate change report card: science review 2017, science review 2017, pp. $124-$ 154. 
Jones P.D. (1988). Hemispheric surface air temperature variations: Recent trends and an update to 1987. Journal of climate,1: 654- 660.

Leigh A. B. and Wulfhorst J.D. (2017). Crop consultants as "Climate Consultants" An Extension Opportunity for Climate Change Communication, Journal of Extension, February 2017, 55(1).

Graeme M. and Edward A. (2009). Climate change, Fisheries, Trade and Competitiveness: Understanding impacts and formulating responses for common wealth small states. Common wealth secreatariat, Poseidon, Worldfish, UK, pp:103.

Maged M.A. Hussein and Ebtisam E.E. Mohamed (2016). Temperature trend over Nile Delta, Egypt in $20^{\text {th }}$ century, Advances in research,7 (2): 1-14.

Schaefer D. and Manfred D. (2009). Recent climate change in Japan, Spatial and temporal climate of the past,5: 13-19.

The General Authority for Fisheries Development (GAFRD), (2016). Year-book of fishery statistics, Cairo, Egypt.. 